\title{
Evidence of $\beta$ cell dysfunction which does not lead on to diabetes: a study of identical twins of insulin dependent diabetics
}

\author{
D A HEATON, B A MILLWARD, P GRAY, Y TUN, C N HALES, D A PYKE, \\ R D G LESLIE
}

\begin{abstract}
Ten non-diabetic identical twins of insulin dependent diabetics were studied to see whether they showed changes in insulin secretion. The twins were selected because $(a)$ more than 11 years had elapsed since the diagnosis of the diabetic twin and they were therefore unlikely to develop diabetes, and $(b)$ they had had islet cell antibodies. Despite similar glucose concentrations to the controls the twins had greater total immunoreactive insulin responses to both oral (mean 3280 (SD 699) versus 2338 (1110) pmol/dl at 180 minutes; $p<0.05$ ) and intravenous (1346 (690) versus 699 (294) pmol/dl at 30 minutes; $p<0.05$ ) glucose challenge. The $C$ peptide responses to intravenous glucose were also increased consistent with increased insulin secretion. In addition, basal serum proinsulin concentrations in the twins were increased $(2.1(1.2)$ versus $1.0(0.3) \mathrm{pmol} / \mathrm{dl} ; \mathrm{p}<0.01)$ and remained so throughout both tests.
\end{abstract}

These twins, who were unlikely to develop insulin dependent diabetes, showed evidence of $\beta$ cell dysfunction which does not progress to diabetes.

\section{Introduction}

Insulin dependent diabetes mellitus is due to destruction of the insulin secreting cells of the pancreas. An immune process associated with diabetes, characterised by the production of islet cell antibodies, may also occur in the non-diabetic identical twins of insulin dependent diabetics. ${ }^{12}$ In some twins these immune changes remit without leading on to the disease ${ }^{2}$; we wondered if these twins showed evidence of alterations in insulin secretion consistent with damage to their $\beta$ cells. We therefore studied a group of nondiabetic twins who had had islet cell antibodies but who could no longer be expected to develop insulin dependent diabetes mellitus.

\section{Patients and methods}

We studied 10 non-diabetic identical twins. ${ }^{1}$ All were more than 11 years from diagnosis of the diabetic twin (range 11-23 years), and we calculated that the risk of any one of the twins developing insulin dependent diabetes mellitus was less than $3 \%$. All the twins had had islet cell antibodies previously (six with complement fixing antibodies). The twins were compared with controls sought from unrelated subjects, not attached to the hospital, who were selected to achieve a similar distribution for age (mean 29.0 (SD 14.0) $v 28.7(10.9)$ years), sex (five women in each group), and body mass index (mean $\left.21 \cdot 1(3 \cdot 7) v 21 \cdot 9(3 \cdot 3) \mathrm{kg} / \mathrm{m}^{2}\right)$. The study was approved by the hospital ethical committee.

\footnotetext{
Department of Medicine and Diabetes, King's College Hospital, London SE5 9RS

D A HEATON, BSC, research biochemist

B A MILLWARD, MRCP, MRC research fellow

Y TUN, BSC, research biochemist

D A PYKE, FRCP, consultant physician

R D G LESLIE, MD, Wellcome Trust senior fellow and consultant physician

Department of Clinical Biochemistry, Addenbrooke's Hospital, Cambridge P GRAY, MD, research fellow

C N HALES, MD, professor of clinical biochemistry

Correspondence to: Dr Leslie.
}

Oral glucose tolerance test-Subjects were studied fasting 15 minutes after having a venous cannula inserted into an antecubital vein. After basal blood samples were taken at -10 and 0 minutes $75 \mathrm{~g}$ glucose $($ or $1.75 \mathrm{~g} / \mathrm{kg}$, whichever was less) dissolved in 0.33 litres of water was consumed over four minutes. Further samples were taken at 10, 30, 60, 90, 120, and 180 minutes for measurements of whole blood glucose, serum insulin, $C$ peptide, and proinsulin concentrations.

Intravenous glucose tolerance test-At 180 minutes after oral glucose was taken glucose $(0.5 \mathrm{~g} / \mathrm{kg})$ was administered through the venous cannula over two minutes. Further samples were taken at $3,5,7 \cdot 5,10,15,20,25$, and 30 minutes. Whole blood glucose was analysed by a glucose oxidase method (Yellow Springs analyser) and haemoglobin $A_{1}$ by electroendosmosis (Corning Instruments). Serum insulin and $C$ peptide values were measured by double antibody radioimmunoassay. ${ }^{34}$ Serum proinsulin concentration was measured by a monoclonal antibody two site immunoradiometric assay. ${ }^{5}$ Intravenous glucose clearance rates were calculated by a method of least squares from 195 to 210 minutes. Insulin responses were calculated as areas under the curve above the basal value using a method of least squares from time 0 to 180 minutes after oral glucose and from 180 to 210 minutes after intravenous glucose. Since peripheral immunoreactive insulin concentrations do not represent the insulin secreted we also measured $C$ peptide, which accurately reflects insulin release while insulin secretion rises, though the relation is lost as insulin concentrations fall. ${ }^{6}$ We therefore calculated the $\mathrm{C}$ peptide response as the sum of the change from basal to 10,30 , and 60 minutes after oral and to three and five minutes after intravenous glucose.

Statistics-Results are expressed as the mean and standard deviation (SD). Changes were compared using a two tailed Student's $t$ test for unpaired observations. The significant variables approximated normal distribution in that $66 \%$ of the values fell within one SD of their mean except when the results of Wilcoxon's rank sum tests were presented. Confidence intervals were calculated on log transformed data for non-parametric results. Results were considered significant at $\mathrm{p}<0.05$.

\section{Results}

Fasting concentrations-The twins and their controls had similar mean blood glucose concentrations $(4 \cdot 0(0 \cdot 6) v 4 \cdot 3(0 \cdot 3) \mathrm{mmol} / \mathrm{l})$, haemoglobin $A_{1}$ values $(6.4(0.6) \%$ v $6.6(0.6) \%)$, mean serum immunoreactive insulin concentrations $(5 \cdot 1(2 \cdot 4) v 5 \cdot 5(3 \cdot 3) \mathrm{pmol} / \mathrm{dl})$, and mean serum $\mathrm{C}$ peptide concentrations $(37 \cdot 3(19 \cdot 3) v 44 \cdot 7(32 \cdot 7) \mathrm{pmol} / \mathrm{dl})$. Mean serum proinsulin concentrations, however, were significantly higher in the twins $(2 \cdot 1(1 \cdot 2) v$ $1 \cdot 0(0.3) \mathrm{pmol} / \mathrm{dl}(\mathrm{p}<0.01)$; mean difference $1 \cdot 1 ; 95 \%$ confidence interval $0 \cdot 1$ to $2 \cdot 1$ )

Response to oral glucose-Blood glucose concentrations in the twins were similar to control values at all time points after glucose (fig 1), while total immunoreactive insulin responses were significantly greater in the twins (3280 (699) v 2338 (1110) pmol/dl at 180 minutes; Wilcoxon rank sum test $p<0.05$; ratio of geometric means $1.49 ; 95 \%$ confidence interval for ratio of means $1 \cdot 0$ to $2 \cdot 2)$. The summed $C$ peptide responses were similar $(241 \cdot 6$ $(124 \cdot 1) v 206 \cdot 6(101 \cdot 3) \mathrm{pmol} / \mathrm{dl})$. Serum proinsulin concentrations remained significantly higher in the twins (fig 2), though the total responses were similar to controls (2729 (1204) $v 1699$ (807) pmol/dl at 180 minutes).

Response to intravenous glucose-At 180 minutes twins and controls had similar blood glucose values (fig 1$)$, serum insulin concentrations $(10 \cdot 0(7 \cdot 9)$ $79.9(6.7) \mathrm{pmol} / \mathrm{dl})$, and $\mathrm{C}$ peptide concentrations $(75.0(47 \cdot 7) v 56 \cdot 7(48.7)$ $\mathrm{pmol} / \mathrm{dl})$. Serum proinsulin, however, remained significantly raised in the twins $(3.2(1.2) v 1.7(0.6) \mathrm{pmol} / \mathrm{dl}(\mathrm{p}<0.01)$; mean difference $1.5 ; 95 \%$ confidence interval $0 \cdot 4$ to $2 \cdot 6$ ) (fig 2). After intravenous glucose twins and controls had similar glucose concentrations (fig 1) and glucose clearance ( $\mathrm{kg}$ ) $(2 \cdot 3(0.6) \% v 2.4(1 \cdot 2) \% / \mathrm{min})$. In the twins, however, the total immunoreactive insulin responses were significantly greater $(1346(690) v 727(294)$ $\mathrm{pmol} / \mathrm{dl}$ at 30 minutes; mean difference $619 ; 95 \%$ confidence interval 95 to $1143 ; \mathrm{p}<0.05)$, as were both the summed $\mathrm{C}$ peptide responses $(217 \cdot 2(146 \cdot 3)$ $v 65 \cdot 1(100 \cdot 1) \mathrm{pmol} / \mathrm{dl}$; Wilcoxon rank sum test $\mathrm{p}<0.05)$ and the total $\mathrm{C}$ peptide responses $(2119 \cdot 5(1265 \cdot 5) v 1023 \cdot 1(1025 \cdot 3) \mathrm{pmol} / \mathrm{dl}$ at 30 minutes; 

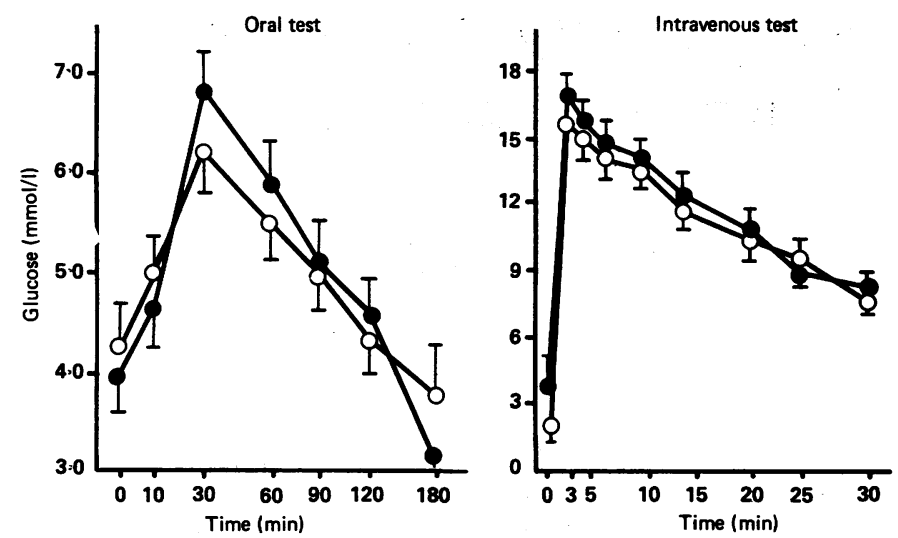

FIG 1 -Responses to oral and intravenous glucose tolerance tests in twins $(O)$ and controls $(\mathrm{O})$. Bars are SD.
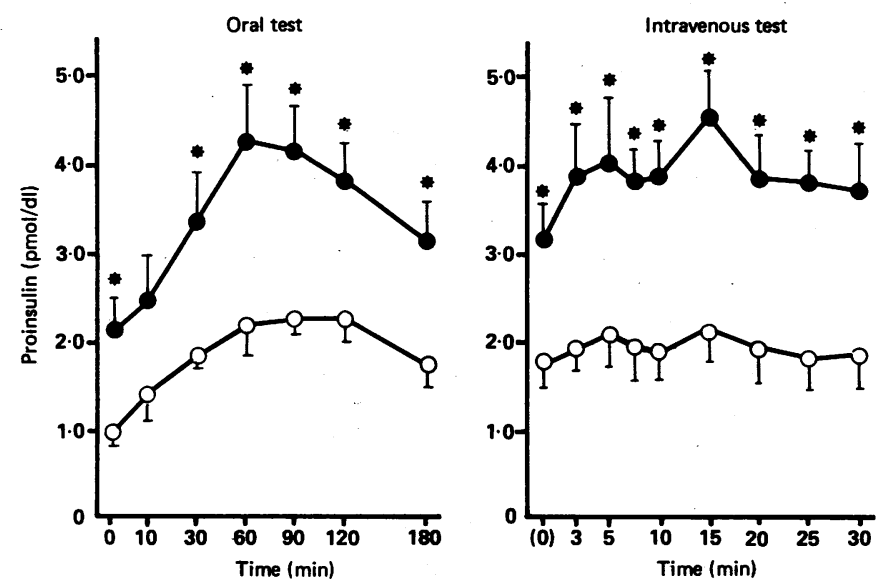

FIG 2-Proinsulin concentrations in twins ( $(\mathrm{O}$ are $\mathrm{SD} .{ }^{\star} \mathrm{p}<0.05$.

Wilcoxon rank sum test $\mathrm{p}<0.05$; ratio of geometric means 2.08 ; $95 \%$ confidence interval for ratio of means $0 \cdot 17$ to $7 \cdot 43$ ). The difference in the total proinsulin responses between twins and controls was not significant (244 (59) v 86 (36) $\mathrm{pmol} / \mathrm{dl}$ at 30 minutes).

\section{Discussion}

Identical twins of insulin dependent diabetics have evidence of $\beta$ cell dysfunction which does not progress to insulin dependent diabetes mellitus. These twins, despite normal glucose concentrations, had increased immunoreactive insulin and C peptide responses to intravenous glucose, consistent with increased insulin secretion. The changes in $\beta$ cell secretion were not confined to insulin as basal proinsulin was raised and remained significantly higher than control values throughout.

Insulin radioimmunoassay may be affected by several factors which interfere with the binding of the anti-insulin antibody to insulin. Two such factors are relevant to this study: insulin autoantibodies and proinsulin. Insulin autoantibodies could compete for the radiolabelled insulin in the insulin radioimmunoassay; some non-diabetic twins of insulin dependent diabetics have such autoantibodies. ${ }^{7}$ We believe that insulin autoantibodies are unlikely to account for the increased insulin concentrations after intravenous glucose because $(a)$ the insulin response was increased but the basal values were not and $(b) C$ peptide concentrations were similarly increased.

Proinsulin binds to the insulin antibody used in the insulin radioimmunoassay. In our assay proinsulin has $70 \%$ of the immunoreactivity of insulin. It is unlikely that the increased proinsulin concentrations in the twins accounted for the increased immuno- reactive insulin concentrations since we calculate that proinsulin could contribute no more than $1.5 \mathrm{pmol} / \mathrm{dl}$ to the difference of 35 $\mathrm{pmol} / \mathrm{dl}$ in immunoreactive insulin values. We conclude that insulim responses were increased in the twins after intravenous glucose.

The twins had increased insulin secretion with normal glucose? clearance after intravenous glucose. These changes might be consistent with insulin resistance; however, the normal basal insulin and glucose concentrations suggest that the twins were not insulinf resistant.

Thus a process which in some twins is associated with complete: destruction of the insulin secreting cells is in others associated withs $\beta$ cell dysfunction which does not progress to diabetes.

This study was supported by the Wellcome Trust, Medical Research Council, Novo, Eli Lilly, King's College Hospital Joint Research Com $\bar{\nabla}$ mittee, and the British Diabetic Association. Tests for islet cell antibodies

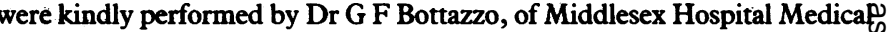
School, London. We are grateful to Dr Bruce Frank (Eli Lilly Company, Indianapolis, USA) for a gift of biosynthetic human proinsulin.

\section{References}

Barnett AH, Eff C, Leslie RDG, Pyke DA. Diabetes in identical twins. A study of 200 pairs Diabetologia 1981;20:87-93.

2 Millward BA, Alviggi L, Hoskins PJ, et al. Immune changes associated with insulin dependen diabetes may remit without causing the disease: a study in identical twins. Br Med fo 1986;292:793-6.

3 Morgan DR, Lazarow A. Immunoassay of insulin: two antibody system. Diabetes 1963;20:1-9. 4 Heding LG. Radioimmunological determination of human C-peptide in serum. Diabetologia of 1975;11:541-8.

5 Gray IP, Siddle K, Frank BH, Hales CN. Use of monoclonal antibodies to human proinsulin in a specific two-site immunoradiometric assay. Diabetes Research and Clinical Practice 1985;suppl-
1:S204-523 (A).

6 Polonsky K, Frank B, Pugh $W$, et al. The limitations to and valid use of C-peptide as a marker of theC secretion

7 Wilkin T, Hoskins PJ, Armitage M, et al. The value of autoantibodies to insulin as serum markers? for insulin-dependent diabetes mellitus. Lancet 1985; i:480-2.

(Accepted 12 November 1986)

\section{YEARS AGO}

An instructive example of the facility with which milk may become the $\overrightarrow{\bar{\sigma}}$ medium for the propagation of a zymotic disease is afforded by a limited 3 epidemic of cholera which occurred on board a sailing ship, the Ardenclutha, lying in the port of Calcutta. Dr. W.J. Simpson, the health officer of? Calcutta, investigated the outbreak with great care, and in a most admirable report, published in the Indian Medical Gazette, offers strong evidence that the outbreak was not to be traced to any peculiar climatic condition, to the state of the ship, to the water, or to any circumstances connected with the visits of the men on shore. Pursuing the inquiry, it was ascertained that ten of the men had used milk supplied by a native who visited the ship daily; of these ten men nine were affected; four died of cholera, and five had severe diarrhoea. With regard to one other man who was the last to suffer fromo cholera, it was doubtful whether he drank any of this milk or not; as he sickened after the others, he may have contracted the disease from an earlier case. Only one man who drank the milk escaped, and he only took a very small quantity. The native who supplied the milk kept one cow, which was in good health, but he frankly admitted that the milk he supplied to ther sailors contained about 25 per cent. of added water; and it also came out that several of his neighbours had suffered from cholera. A case had been $\omega$ imported on March 2nd; the dejecta from this patient drained into the tank on which the milkman's house stood. The first case among the milkman' neighbours occurred on March 7th; the first case of diarrhoea among the crew of the Ardenclutha on the same day, and the first case recognised as: cholera two days later. This, taken along with the admission that water was added to the milk, and that, with one exception, the remainder of the crew, fourteen in number, who had not drunk the milk, did not suffer from cholera or diarrhoea, leaves very little doubt as to the origin of the epidemic. The milk was clearly the connecting link between the epidemic in the hamlet and on board the ship, and it was without much doubt rendered infective by the addition of the tank water fouled by the dejecta of the imported case. The investigation also shows that cholera, while prevailing in a distant locality may be established simultaneously at two widely different places, and yet be due to a common cause which is preventable. (British Medical Fournal 1887;ii:82.) 